Archived version from NCDOCKS Institutional Repository http://libres.uncg.edu/ir/asu/

\title{
Appalachľan
}

$\overline{B \text { O O N E, N O R T H C A R O L I N A }}$

\section{Funding Sustainable Paddle Trail Development: Paddler Perspectives, Willingness To Pay And Management Implications}

\author{
By: Carol Kline, David Cardenas, Lauren Duffy, and Jason R. Swanson
}

\begin{abstract}
Paddle sports (kayaking, canoeing) are a growing tourism niche and an activity that can bring sustainable rural tourism development and economic regeneration. Managing sustainable paddle trail growth is complex, involving coordination among government bodies, consensus from landowners and funding acquisition for safe access sites, signage, maps and other amenities. This paper explores the paddle-trail-related literature and the many different funding options to manage the creation and maintenance of paddle trails. An Internet survey of 1851 respondents determined support for a variety of user funding mechanisms for trail development as well as paddler perceptions about trail development as a viable form of economic development. The results indicate that women and recreational paddlers are more likely to support funding mechanisms, in addition to paddlers who consider paddle trail development a form of economic development. Paddlers who did not support any user funding mechanism were male, employed in the private sector, avid paddlers, and those who owned boats. It is observed that awareness of paddle trails' value as an economic regeneration tool increases the willingness to pay. A range of management implications from this research are discussed, including information and educational programs, marketing partnerships and targeted incentive offers to those groups that are unwilling to pay.
\end{abstract}

Carol Kline, David Cardenas, Lauren Duffy \& Jason R. Swanson (2012) Funding sustainable paddle trail development: paddler perspectives, willingness to pay and management implications, Journal of Sustainable Tourism, 20:2, 235-256, DOI: 10.1080/09669582.2011.603425. Publisher version of record available at: https://www.tandfonline.com/doi/abs/10.1080/09669582.2011.603425 


\title{
Funding sustainable paddle trail development: paddler perspectives, willingness to pay and management implications
}

\author{
Carol Kline $^{\mathrm{a} *}$, David Cardenas ${ }^{\mathrm{b}}$, Lauren Duffy ${ }^{\mathrm{c}}$ and Jason R. Swanson ${ }^{\mathrm{d}}$ \\ ${ }^{a}$ Recreation and Leisure Studies, Center for Sustainable Tourism, East Carolina University, \\ Greenville, North Carolina, USA; ${ }^{b}$ Center of Economic Excellence (CoEE) and Tourism and \\ Economic Development, School of Hotel, Restaurant, and Tourism Management, University of \\ South Carolina, Columbia, USA; ${ }^{c}$ Recreation, Parks, and Tourism Studies, Indiana University \\ Bloomington, USA; ${ }^{d}$ Hospitality Management and Tourism Program, University of Kentucky, \\ Lexington, USA
}

\begin{abstract}
Paddle sports (kayaking, canoeing) are a growing tourism niche and an activity that can bring sustainable rural tourism development and economic regeneration. Managing sustainable paddle trail growth is complex, involving coordination among government bodies, consensus from landowners and funding acquisition for safe access sites, signage, maps and other amenities. This paper explores the paddle-trail-related literature and the many different funding options to manage the creation and maintenance of paddle trails. An Internet survey of 1851 respondents determined support for a variety of user funding mechanisms for trail development as well as paddler perceptions about trail development as a viable form of economic development. The results indicate that women and recreational paddlers are more likely to support funding mechanisms, in addition to paddlers who consider paddle trail development a form of economic development. Paddlers who did not support any user funding mechanism were male, employed in the private sector, avid paddlers, and those who owned boats. It is observed that awareness of paddle trails' value as an economic regeneration tool increases the willingness to pay. A range of management implications from this research are discussed, including information and educational programs, marketing partnerships and targeted incentive offers to those groups that are unwilling to pay.
\end{abstract}

Keywords: paddle trail; funding; fees; resource management; economic development; tourism

\section{Introduction}

For over 50 years, rural communities contended with the decline in the agricultural and manufacturing sectors, and the migration of youth to urban areas (Briedenhann \& Wickens, 2004). Governments, community planners, researchers and business leaders have recognized tourism as an economic rural regeneration strategy (Gallardo \& Stein, 2007; Pouta, Neuvonen, \& Sievanen, 2006). Nature-based tourism has played an important role in that development, creating more revenue than many other forms of land use, fostering positive environmental management strategies and helping retain and develop local infrastructure (Turner, 2001). Within the US, paddle trail development is being used as a catalyst to

\footnotetext{
*Corresponding author. Email: ckline7@nc.rr.com
} 
attract canoeists and kayakers, and capture a growing component of nature-based tourism (Thigpen, Avant, \& Siderelis, 2001).

Paddle trail development is a small but important component of sustainable tourism. It is a low-carbon activity and can be developed relatively close to many centers of population. It can help use tourism as a low impact tool for rural regeneration (Lane, 1994, 2009). It forms part of the growing interest in slow tourism (Dickinson, Lumsdon, \& Robbins, 2011; Lumsdon \& McGrath, 2011). But it typically requires external funding if it is to create the "triple-bottom line" benefits from its development. In that sense, it is typical of many rural tourism developments using common pool resources (Moore \& Rodger, 2010). Destination and waterway managers must, therefore, explore a variety of funding options to help develop the infrastructure needed to attract visitors. This study explores support for a variety of user funding mechanisms for paddle trail development as well as paddler perceptions toward trail development as a viable form of economic development in North Carolina (NC), USA, specifically asking:

(1) Are there differences in perceptions of paddle trails as an economic development tool among different types of paddlers?

(2) Are there differences in support for paddle trail funding mechanisms among different types of paddlers?

\section{The growth of paddle sports}

Ken Cordell (2008) cites kayaking as one of the fastest-growing US nature-based outdoor activities, with an estimated 12.5 million participants, representing a $63 \%$ increase from 2000 to 2007 . Within NC, approximately 664,000 residents participate in kayaking and/or canoeing, of which kayaking has increased by $260 \%$ and canoeing by $31 \%$ from 2002 to 2007 (North Carolina Division of Parks and Recreation [NCDPR], 2008).

The increase in paddle sports participation has led to the growing demand for paddle trail development in rural areas (Settina \& Kauffman, 2001), with issues related to development, such as funding and stakeholder support, brought to the forefront. Rural communities often do not have the funds to leverage their resources for developing access sites, signage or other paddle trail infrastructure. Additionally, buy-in and consensus on resource management between paddlers, landowners, resource managers, elected officials, local agencies and a variety of other stakeholders is difficult to achieve, yet is critical for the success of a paddle trail project (Trask, 2006). Consensus-building among diverse stakeholder groups and the development of appropriate funding mechanisms for sustaining and building trails are interlinked throughout the entire process. The literature on paddle sports, particularly on paddlers' views of their own pastime as an economic development tool, and the issues surrounding funding are reviewed next.

\section{Perceptions of paddle trails as an economic development tool}

In their economic assessment of human-powered outdoor recreation in the US, Southwick, Bergstrom, and Wall (2009) determined the total direct, indirect and induced economic impact of paddle-based recreation to be over $\$ 36$ billion and an employment of over 308,000 people per year. Nationally in 2005, 87 million day trips were taken and 23 million paddlers participated in over 80 million overnight paddling trips. Many state-level and regional studies have also estimated the economic impact of paddle trails (Pollock, 2007; Thigpen, Avant, $\&$ Siderelis, 2001). The National Park Service offers a guide on a variety of techniques for 
estimating the economic impact of rivers, trails and greenway corridors, including methods related to real property values, outdoor recreation expenditures by residents, commercial uses, agency and business spending related to the resource, expenditures by visitors, corporate relocation and retention, public cost reduction from nature and multiplier effects. The guide was updated later to include gateway communities, educational value, green infrastructure, and retirement relocation and retention (Nadel, 2005). Krizek (2007) discusses how to calculate the economic cost of right-of-way preservation. However, despite the ready information touting trails as an economic engine within communities, very little is known regarding people's view of this matter. Schutt suggests using trails as part of a local economic development strategy, stating that "economic benefit and impact studies of trails should be taken one step further, to become part of a local economic development strategy" (1998, p. 127). In order to adapt this strategy, it would be useful to understand which community members support this view, and which do not.

There are few published studies that focus specifically on examining perceptions of paddle trails as an economic development tool. But it should be recognized that paddle trails have similar characteristics to those of the heavily studied greenways and walking/cycle trails. Therefore, a brief overview of the numerous studies looking at perceptions of greenways and land trails is given below. Often, this research focuses on the views of landowners who own property near or adjacent to the trail (Jennings, 2010; Lindsey, Man, Payton, \& Dickson, 2004; Nicholls \& Crompton, 2005) and the trail user (Mowen, Graefe, $\&$ Williams, 1998), or the perception surrounding the general benefits that trails and greenways create (see http://www.americantrails.org/resources/benefits/index.html). Moore and Shafer (2001) additionally note that managers view trails and greenways as facilities, and the maintenance of these facilities comes with a host of challenges. Rarely are users, managers and the public at large surveyed regarding their views of trails, and particularly paddle trails, as an economic development tool. One exception is examining adjacent landowners' views of trails' effect on their property values (Nicholls \& Crompton, 2005). While previous research has suggested or attempted to calculate the economic benefits of better individual health, decreased pollution, reduced congestions and accidents, and increased expenditures by tourists, few researches have gained a perspective on who view trails as having an economic development potential. Examining perceptions of the economic value of trails, as well as understanding if it is perceived to be an economic development tool, has important implications for managers. Specifically, assessing these aspects helps to justify the implementation of funding strategies or funding requests to administering agencies $(\mathrm{Oh}$ $\&$ Hammitt, 2010). However, while there is currently enough academic literature to support the economic value of trail benefits, it is unclear whether various stakeholders have adapted these views. To begin this discussion on perceptions of trail value, this paper therefore explores the economic benefits of trails.

After reviewing 25 studies that examined the economic dimensions of municipal and regional bicycle facilities, Krizek (2007) notes that the range of financial benefits should be described, in addition to identifying whom they benefit. He categorizes six kinds of associated economic benefits of biking: mobility and health and safety benefits that are direct to the user; and decreased externalities, increased livability and fiscal savings as benefits to society. Additionally, in a study of urban greenway users, Shafer, Lee, and Turner (2000) found that trails were considered as contributing most greatly to qualityof-life issues, and less to diversifying industry and business development. Water trails are part of the larger field of recreational trail management and may run concurrently with or connect to other types of trails such as greenways, rail-trails or backcountry trails (Moore $\&$ Shafer, 2001). The research on water trails, blueways or paddle trails, in all of its various 
names, is explored less frequently in the literature than the land-based counterparts. One instance is a study by Jennings (2010), who explored the attitudes of landowners before and after the opening of the Luling Paddle Trail in Texas. Most of the 19 respondents in that study did not feel that the trail adversely affected their property values, and there was no significant change in their attitude after the trail was opened.

The current study addresses the paddlers' view of paddle trails as an economic development tool and that view's relationship to their support for funding schemes. In particular, socio-demographics, paddlers' experience level and boat ownership are explored. The first set of research hypotheses are:

H1: Socio-demographic variables such as gender, age, household income and employment sector will not impact the paddler's view of paddling as an economic development tool.

\section{H2: Boat ownership will not impact the paddler's view of paddling as an economic development tool.}

H3: Paddler's experience level will not impact his/her view of paddling as an economic development tool.

H4: Paddler's view of paddling as an economic development tool will not impact his/her support for paddle trail funding mechanisms.

After reviewing the literature, it is expected that the Hypothesis 1 will not be rejected, as socio-demographic variables would not likely play a role in a paddler's view of paddle trails. However, it is expected that Hypotheses 2 and 3 would be rejected in that more experienced paddlers or paddlers who own boats would be more familiar with the costs associated with the sport and would translate these costs into economic benefits for the paddling destination. Similarly, it is expected that Hypothesis 4 would also be rejected. The importance of examining this relationship is to better understand whether those who view nature-based activities as an economic development tool would then be more willing to support the growth of that activity. Ultimately, this study aims to assess whether or not perceiving a nature-based activity, in this case paddling, as a tool for economic development would then affect the perceptions toward funding mechanisms needed to develop and maintain the facilities necessary to have the activities. This literature review goes on to look at the funding issues for paddle trail development and various willingness-to-pay (WTP) models.

\section{Funding for paddle trail development}

Paddle sports feature in two main areas of the literature: the first relates to participation in and the effects of paddle sports on the participants (Bixler \& Morris, 2000), the second concerns issues in paddle sports as part of nature-based tourism, including crowding, user conflicts, concessionaire oversight, boater permit, user safety, parking, human waste, water quality, resource monitoring, neighborhood landowner relations, state and federal regulations (Siderelis \& Moore, 2006, p. 558), divergent stakeholders' views (Shafer \& Choi, 2006), access management, access funding, and visitor experience (Braswell \& Byrd, 2006). More recently, researcher (and manager) interest in the economic and managerial aspects of paddle sports has grown. This research includes studies that have investigated participation levels and demand (Cordell, 2008), management practices and policy issues of nature-based tourism (Grossmann, Klaphake, \& Meyerhoff, 2004), and WTP models and funding mechanisms for paddle sports (Siderelis \& Moore, 2006; Siderelis, Whitehead, \& Thigpen, 2001).

Braswell and Byrd (2006) noted that funding for access is difficult to generate, and that development and management strategies and long-term funding options are major issues 
in non-motorized boating. Local groups on watershed capacity-building also note that establishing innovative revenue-producing programs and obtaining private grants are major issues in river management, along with budgeting and grant writing (US Environmental Protection Agency, 2003). Obtaining adequate funding for recreational resource development, management and maintenance has been a serious federal government issue since the 1980s; many states have introduced or increased fee-based programs as a means for offering more recreational services (Cordell \& Betz, 2000). Cordell and Betz noted that "to combat funding shortfalls, states have moved rapidly towards greater self-sufficiency through programs aimed at dramatically increasing revenues. From 1975 to 1995, state park system revenues increased $384 \%$ while legislatively appropriated funding rose only $286 \%$ " (2000, p. 87). Locally operated recreation facilities are also under-funded. Fees for recreation on public lands are often criticized as decreasing access for lower-income citizens (Harris \& Driver, 1987). Advocates for fees propose that they ultimately stimulate the overall economy:

While the direct effect of recreation fees is to reduce use, the indirect effects will increase recreational opportunities. Private investment in recreation will become more profitable. Increased investment in recreation on public lands will occur through the political economy of the budget process. That, in short, is the economic case for increasing recreation user fees. (Binkley \& Mendelsohn, 1987, p. 35)

Debating the merits and demerits of user fees is beyond the scope of this paper; for a brief summary on the issues around recreation fees, see Bowker, Cordell, and Johnson (1999).

Traditionally, funds for local trails projects in the US have been acquired through Federal Transportation Enhancements, land and water conservation funds, state legislative allocations and recreational trails programs (Portland Parks \& Recreation, 2006). Bond measures, donations, sponsorships, "friends of" programs, license plate initiatives and special events are other common sources of fund-raising, as are concessionaire contract fees and special-use permits charged to outfitters and guides. Additionally, a number of measures can be enacted at different governmental levels and passed to users, including access or user fees, licenses and taxes on related equipment. The River Federation (1997) found that while legislative appropriation and voter-approved bonds are the most common sources, others such as cooperative agreements, contracts with state agencies, river recreation fees and fishing licenses help add to the state's budget.

WTP studies are prevalent in the outdoor recreation field (see Argow \& Fedkiw, 1963; Binkley \& Mendelsohn, 1987) and aim to help resource managers gauge an appropriate threshold for user funding mechanisms. Funding mechanisms may be in the form of an annual pass, an equipment tax, a license for use, boat registration or a pay-to-play scenario where the recreationists pay each time they wish to have access to a particular resource (e.g. campsite, lake, trail or ski slope). Fees may offset maintenance of a particular facility, such as a boat ramp, bathroom or shelter (Watson \& Herath, 1999), or may contribute to the overall operations of public lands. Many publications on fee structure and support for fees concentrate on public lands at the national level, particularly the National Park System or US Forest Service (Nyaupane, Graefe, \& Burns, 2009; Ostergren, Solop, \& Hagen, 2005). Others focus on a specific local recreation site. While some studies focus on users' satisfaction with current fees (Marsinko, Dwyer, \& Schroeder, 2003) or preferences among different types of hypothetical fees (Ostergren, Solop, \& Hagen, 2005), others investigate the effects of fees on recreation participation (Siderelis \& Moore, 2006; Siderelis et al., 2001) or the factors that influence support of fees (Lee, Lee, Kim, \& Mjelde, 2010; Nyaupane et al., 2009; Winter, Palucki, \& Burkhardt, 1999). 


\section{Socio-demographic differences in willingness to pay}

Some research has explored the socio-demographic characteristics of recreationists to determine whether there is a relationship between characteristics and fee support. Part of the 1995 NSRE (National Survey on Recreation and the Environment) examined public opinion toward user fees to fund recreation services and amenities on public lands. Respondents in the southern US were less likely to support any fees than northern and western respondents, and younger and more educated respondents were more likely to support fees (Bowker et al., 1999). Ethnicity and income have various effects on the support of fees. In a study of potential equity effects of a proposed recreation fee, Reiling, Cheng, Robinson, McCarville, and White (1995) found no relationship between recreational user fees and ethnicity. However, in a later research on ethnicity and recreation demand in the Florida Keys, Bowker and Leeworthy concluded that Hispanics were more sensitive than others to increased travel costs, stating higher access fees could dramatically change the "ethnic distribution of recreation visitors to the Keys" (1998, p. 74). Caucasians and Asians (combined as one variable) were more likely to support fees than African-American and Hispanic respondents. Higher-income respondents were more likely to support fees (Bowker et al., 1999). In exploring attitudes about boat ramp fees, Southerners were less likely to support user fees, while female respondents as well as respondents with higher education, higher income and those who were Caucasian/Asian were more likely to support fees. Age was not found to be significant. In their study of South Carolina park users, Oh and Hammitt (2010) found that age did not have an effect on park users' willingness to pay additional entrance fees, and that increased fees would not displace different income-based user groups disproportionately.

In a phone survey conducted in 2000, Ostergren, Solop, and Hagen found that race, ethnicity, age, income, education and whether the respondents had visited a national park unit are all significantly related to the perception that entrance fees are too high. Age was weakly related to this perception, while race, ethnicity, income, education and visitor status were moderately related. Kyle, Graefe, and Absher (2002) found that household income did not significantly correlate with the respondents' concept of WTP, while Fix and Vaske (2007) noted that respondents with lower incomes held different beliefs regarding fees and showed less support than those with higher incomes. Lee et al. (2010) found age to be significant in their WTP study on birding tours. They found that the probability of participation in bird-watching options increases as the respondent's age increases.

Studies by Winter et al. (1999) and Nyaupane et al. (2009) explored WTP in relationship to social trust of federal land management agencies. Winter et al. (1999) found social trust, age and ethnicity to have the most impact on fee-related attitudes and WTP scenarios, while Nyaupane et al. (2009) found that only equity belief influenced acceptance of fees. The latter study highlights the contradictions found in fee-based literature about the relationship between income and fee acceptance and emphasizes that the perceptions of equity influenced by trust play an intermediating role. Mowen, Kyle, Borrie, and Graefe (2006) used socio-demographic and trust/commitment variables to explore support for various park and recreation funding and cost-saving mechanisms in a region of Pennsylvania. The strategies most strongly supported were donations and corporate sponsorships, followed by intergovernmental cost sharing, general taxes, park programming and "sin" taxes, i.e., taxes placed on products such as alcohol and cigarettes. Park privatization and entrance fees were viewed as the least favorable options. They found that age and income were related to sin tax support, fee-based strategies and external contributions such as donations and sponsorships. Older respondents and respondents with higher household incomes were less likely to support the use of sin taxes as a park funding strategy. Older respondents were 
more likely than younger respondents to support park entrance fees as a funding strategy but less likely to support donations/philanthropy as a park funding strategy. Respondents with a lower income were less likely to support park programming fees as a funding strategy and those with a higher income were less likely to support donations/philanthropy.

In 1996, Glaser and Hildreth conducted a study to explore the relationship between citizens' willingness to pay taxes and their usage patterns for parks and recreation facilities. They found that women were over-represented in the group that expressed high demand for park and recreation services and high WTP for investment in parks and recreation facilities through increased taxes. In comparison, males appeared slightly more likely to be philanthropists, indicating overpayment of taxes in relation to their demand for facilities. Traditionalists, or those with continuity between facility usage patterns and willingness to pay taxes, disproportionately included lower-income households. Additionally, groups whose demand outweighed their willingness to pay taxes were least likely to contain citizens with household incomes of less than $\$ 25,000$. Older, smaller households did not support tax increases and were also limited users of parks and recreation facilities.

\section{Skill level and boat ownership differences in willingness to pay}

Involvement studies in the recreation literature explore a variety of factors that influence recreationists' level of commitment to, enjoyment of and identification with their sport. These include elements such as frequency and longevity of participation (Kim, Scott, \& Crompton, 1997; Kuentzel \& Heberlein, 2006), skill level (Schuett, 1995) and equipment ownership (Kim et al., 1997; Kuentzel \& Heberlein, 2006; Meyer, 1999). Likewise, recreation specialization literature explores those qualities of a recreationist that comprise a style of recreation participation. The recreation specialization concept was developed by Bryan (1977) to explain diversity among participants in a given activity. He purported that within any activity, there are distinct tiers of participants who have particular types of involvement. These types of involvement are reflected by skill level, equipment and setting preferences, attachment, attitudes toward resource management, the social context of involvement and centrality to life (Bryan, 1977).

Lee, Graefe, and Li (2007) examined the effects of specialization on motivations and preferences for site attributes in paddling. Their dimensions of specialization included participation, equipment (number and kind of boats owned), skill level (self-rated as novice, intermediate, advanced or expert) and lifestyle/commitment. While the current study is not focused on motivations or site preferences, the Lee et al. (2007) study provides an example of skill level and equipment usage as relational variables in a paddling study. They found that the level of specialization affects paddling motivations and preferences for site attributes. Based on their study, it would appear that specialization level may be utilized in target marketing.

Meyer (1999) discovered differences in recreational involvement according to type of boat - specifically, the larger the boat, the greater the involvement. He also found that boat tourists (boaters not native to the area of study) almost always used larger and betterequipped boats than the local boaters, while the local boaters had a larger variety of boat types. Schuett (1995) used socio-demographics and skill level as independent variables in his study on paddling companions. He measured skill level by asking participants to classify themselves as novice, intermediate or advanced. Experience was measured by the number of years of kayaking and the number of different rivers kayaked in the previous year. He found that "solo paddlers are highly skilled, paddle many times a year, kayak a lower level of river difficulty, are sensation seekers, and have a higher income" (1995, 
p. 49) (the tendency for the sensation seekers to kayak alone compels them to choose rivers with lower difficulty despite wanting a thrilling ride).

Both Hynes, Hanley, and Garvey (2007) and Hynes and Hanley (2006) used a self-rated scale of basic, intermediate or advanced to determine the proficiency of kayakers in their study. The 2007 study found that whitewater kayakers of different skill levels look for different site attributes. The 2006 study found that the intermediate-proficiency kayakers made the most trips, followed by the advanced-proficiency kayakers, who made more trips than the basic-proficiency kayakers. In a study of birders, Moore, Scott and Moore found that "[specialized birdwatchers] make trip decisions based on the birds likely to be seen, whereas casual participants are likely to make trip decisions based on a broader range of destination attributes" (2008, p. 91). In a study of all-terrain vehicle (ATV) riders in Wisconsin, USA, Snyder and Smail (2009) found that advanced skill level had a negative impact on the willingness to pay to ride on public lands.

Based on the above review of the existing literature, this study therefore considers a second set of research hypotheses:

H5: Socio-demographic variables such as gender, age, household income and employment sector will not impact the paddler's support for paddle trail funding mechanisms.

H6: Boat ownership will not impact the paddler's support for paddle trail funding mechanisms.

H7: Paddler's experience level will not impact his/her support for paddle trail funding mechanisms.

It was expected that Hypothesis 5 will be rejected, and that gender, age, income and employment sector will influence paddlers' support for paddle trail funding mechanisms. It was also speculated that boat ownership and paddler's experience level will affect paddler's support for funding strategies, based on the previous research yielding similar findings.

In a paper analyzing the breadth of fee-based research issues, Watson and Herath conclude by asking: "How can we make science an integral part of policy formation?" The authors note the need for scientists to help managers "understand that social science is an integral part of resource management" (1999, p. 332) and that "proceeding with the implementation of access fee policies without the ability to anticipate how various public segments will respond or the ability to actually monitor effects illustrates a lack of concern for the intended function of public lands in the lives of the American people" (1999, p. 332). If natural resource managers had a greater understanding of paddling segments and their support for different funding options, implementation of fee programs might be more successful. While the focus of this study is to determine what kinds of funding mechanisms are acceptable to which types of paddlers, the analysis was grounded less on a question of equity of a funding mechanism and more on a marketing-based quest to determine who might be targeted for support for various funding programs.

\section{Methods}

\section{Study area}

$\mathrm{NC}$ is the sixth most visited state in the US (North Carolina Division of Tourism, Film and Sports Development, 2009), with an estimated 38 million US and Canadian visitors, and 355,000 overseas visitors in 2008. The North Carolina Paddle Trails Association (an organization working to nurture sustainable communities by developing and maintaining paddle trails: http://www.ncpaddletrails.info) notes that NC has over $6000 \mathrm{~km}$ of estuarine and oceanic shorelines, and nearly $61,000 \mathrm{~km}$ of rivers and creeks. The American Canoe 


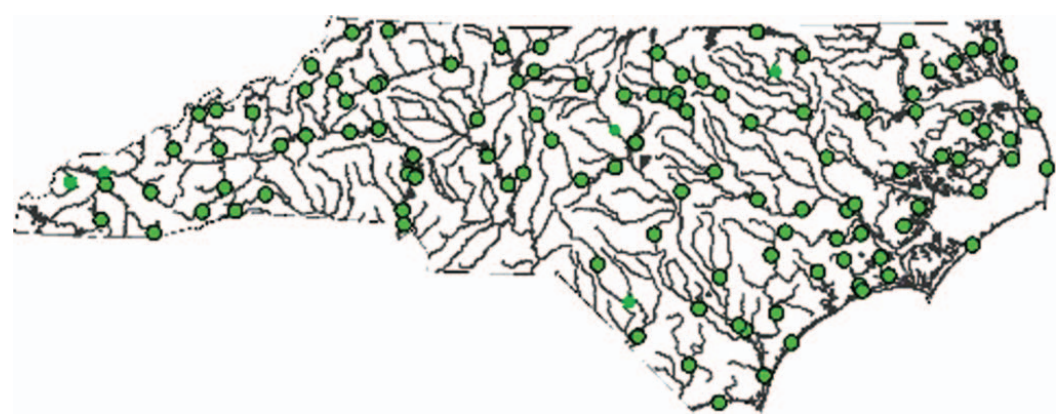

Figure 1. A sample of designated paddle trails in North Carolina.

Association (ACA, n.d.) recognizes over 150 paddle trails within NC. The circles in Figure 1 illustrate the plethora and range of paddle trails around the state. Paddling opportunities include the Atlantic Ocean, inland estuaries, lakes and flat rivers, plus Class I-VI whitewater rivers in the western mountainous region of the state.

The State Trails Program is part of the NCDPR and works with paddle clubs, land trusts, small businesses and communities to develop and maintain terrestrial and water trails. Its programs and facilities are funded by five major sources: the Parks and Recreation Trust Fund, the Clean Water Management Trust Fund, the Natural Heritage Trust Fund, Certificates of Deposit approved by the NC General Assembly and the federal Land and Water Conservation Trust Fund (NCDPR, 2008). Current boat-related fees at state-owned facilities are $\$ 4.00$ for boat ramps per (motorized) boat, $\$ 5.00$ for the first hour of rowboat or canoe rental ( $\$ 3.00$ for each additional hour), $\$ 5.00$ per car $\$ 10.00$ per bus entry and $\$ 40.00$ annual pass to three particular lake recreation areas (North Carolina Administrative Code 15A NCAC 12B.1206).

Additionally, the North Carolina Wildlife Resources Commission provides public access to water for boaters and anglers via 206 boat ramps. The use of the ramps by both motorized and non-motorized crafts are occasional sources of conflict between the two types of boaters, with requests from canoeists and kayakers for separate put-in points. However, sources of funding for such basic infrastructure are currently lacking:

North Carolina Wildlife Resources Commission with responsibilities to provide water access continues to be constrained as far as development efforts for paddlers because there was no funding mechanism in place, which allowed for the construction or maintenance of access sites or launches. The funding mechanism for the Wildlife access sites throughout the state is paid for through a percentage of the tax on gasoline. Since paddle craft are not operated by gasoline engines, this restricts WRC from spending monetary resources to implement or maintain facilities for paddlers. (Trask, 2006, p. 11.)

\section{Survey instrument}

A 26-question survey was designed in collaboration with the NC State Trails Program to assess general trip qualities desired by paddlers, estimate their expenditures and ascertain level of support for various funding mechanisms for paddle trails. A copy of the survey instrument can be found as an appendix to the web-based version of this paper. Participants were specifically asked about possible means for funding improved and increased paddle access. Response options were user fees, canoe/kayak registration, paddling license, sales tax on equipment, other and none. The NC Trails Program was interested in clear "support" 
or "do not support" verdicts for each option; therefore, a dichotomous response option was used; respondents could select the funding option they supported and leave blank for options they did not support. Respondents were also asked: Do you feel that paddle trail development is a viable form of economic development for NC? Response options were Yes, No and I'm not sure.

Survey participants were asked to indicate their self-assessed level of paddling skill (novice, recreational or avid) and whether they owned or rented kayaks/canoes, in addition to indicating their employment sector - public, private, non-profit, retired, student or unemployed - and demographic variables of gender, age and household income.

\section{Survey distribution and statistical techniques}

The survey was adapted to an electronic format using an online software program. Despite the drawbacks of electronic distribution (coverage and sampling error; Dillman, 2000), an online survey was used because of the very low budget available. Care was taken to reduce measurement error through the use of Dillman's (2000) design principles for web surveys, established survey questions and pilot testing. To maximize the response rate, solicitation for the survey was distributed on LISTSERV and through paddle clubs' mailing lists, and through outfitters, state parks and local tourism agencies. Over a period of 130 days, 2153 responses were collected. Of those, only responses of those who resided in NC were included in the study. The data questions were coded and analyzed using SPSS 17.0. A missing value analysis (MVA) in SPSS was conducted; all participants who had more than $5 \%$ of their responses missing were dropped from the study, leaving 1851 respondents in total. Several statistical techniques were used to analyze the data, including descriptive statistics and chi-square, and three-way cross-tabulation. There were two phases of analysis: the first examined Hypotheses 1-4 (factors affecting paddler's perception of paddling as an economic development tool) and the second phase examined Hypotheses 5-7 (factors affecting paddler's funding support).

\section{Results}

\section{Participant characteristics}

A majority of respondents were male (63\%), between 31 and 60 years of age $(75 \%)$. Household income categories showed an even distribution between most income categories, ranging from $\$ 25,000$ to $\$ 149,000$ (Table 1). The largest employment group was the public sector $(47 \%)$. Over half of the respondents classified themselves as recreational paddlers $(59 \%)$. Additionally, more than half of the respondents $(55.5 \%)$ paddled their own kayaks, while one fifth $(21.8 \%)$ used their own canoes.

\section{Paddling as an economic development tool}

Over two-thirds of the respondents (71.0\%) indicated that they felt paddle trail development was a viable form of economic development in NC. Women, $\chi^{2}(1, N=1807)=4.406$, $p=0.031$, were more likely to consider paddle trail development as a viable form of economic development compared with men (Table 2). Novice paddlers, $\chi^{2}(2, N=$ $1822)=7.045, p=0.030$, were less likely to consider paddle trail development as a viable form of economic development compared with recreational and avid paddlers. Finally, the 18-30 and 31-40 year olds were less likely to view paddling as an economic development tool, $\chi^{2}(1, N=1822)=16.199, p=0.030$, while the $51-60,61-70$ and $70+$ year olds, $\chi^{2}(1, N=1822)=16.199, p=0.030$, were more likely to. 
Table 1. Summary data of respondents.

\begin{tabular}{|c|c|c|}
\hline Variable & Percentage & Frequency \\
\hline \multicolumn{3}{|l|}{ Gender } \\
\hline Female & 36.9 & 675 \\
\hline Male & 63.1 & 1152 \\
\hline \multicolumn{3}{|l|}{ Age (years) } \\
\hline $18-30$ & 14.4 & 265 \\
\hline $31-40$ & 23.0 & 423 \\
\hline $41-50$ & 25.5 & 468 \\
\hline $51-60$ & 26.0 & 478 \\
\hline $61-70$ & 9.0 & 165 \\
\hline Over 70 & 2.0 & 36 \\
\hline \multicolumn{3}{|l|}{ Average income } \\
\hline$\$ 1000-24,999$ & 4.7 & 82 \\
\hline$\$ 25,000-49,999$ & 21.8 & 384 \\
\hline$\$ 50,000-74,999$ & 24.1 & 446 \\
\hline$\$ 75,000-99,999$ & 20.5 & 362 \\
\hline$\$ 100,000-149,999$ & 20.3 & 358 \\
\hline$\$ 150,000-199,999$ & 4.8 & 84 \\
\hline Over $\$ 200,000$ & 2.7 & 47 \\
\hline \multicolumn{3}{|l|}{ Employment sector } \\
\hline Nonprofit sector & 8.3 & 150 \\
\hline Private sector & 30.0 & 548 \\
\hline Public sector & 47.0 & 856 \\
\hline Retired & 10.6 & 194 \\
\hline Student & 3.2 & 59 \\
\hline Unemployed & 1.0 & 19 \\
\hline \multicolumn{3}{|l|}{ Paddler type } \\
\hline Novice & 18.5 & 343 \\
\hline Recreational & 59.3 & 1095 \\
\hline Avid & 22.2 & 410 \\
\hline \multicolumn{3}{|c|}{ Equipment used to paddle } \\
\hline Use own kayak & 55.5 & 1020 \\
\hline Use own canoe & 21.8 & 401 \\
\hline Rent a kayak & 7.1 & 133 \\
\hline Rent a canoe & 8.9 & 163 \\
\hline Other & 6.5 & 120 \\
\hline
\end{tabular}

\section{Funding support}

Overall, the majority of respondents $(64.0 \%)$ indicated they would support some type of funding for access and paddle trail development. Four types of funding sources were assessed by those supporting funding, with user fees being the most favorable $(31.0 \%)$, followed by state sales tax on equipment $(28.0 \%)$, canoe/kayak registration $(23.0 \%)$ and

Table 2. Chi-square analysis of economic development variable and socio-demographic and paddler type variables.

\begin{tabular}{lcccc}
\hline Variable & $N$ & $\chi^{2}$ value & df & $p$ \\
\hline Paddling as an economic development tool & & & \\
Gender & 1807 & 4.406 & 1 & 0.031 \\
Paddler type & 1822 & 7.045 & 2 & 0.030 \\
Age & 1822 & 16.199 & 1 & 0.030 \\
\hline
\end{tabular}


Table 3. Chi-square analysis of funding source variables and socio-demographic, paddler type and equipment variables.

\begin{tabular}{lcccc}
\hline Variable & $N$ & $\chi^{2}$ value & df & $p$ \\
\hline User fees & & & & \\
$\quad$ Gender & 1827 & 4.905 & 1 & 0.027 \\
$\quad$ Average income & 1763 & 14.67 & 6 & 0.023 \\
$\quad \begin{array}{l}\text { Sales tax on equipment } \\
\quad \text { Employment }\end{array}$ & 1829 & 13.31 & 5 & 0.021 \\
Canoe/kayak registration & & & & \\
$\quad$ Average income & 1763 & 12.65 & 6 & 0.049 \\
$\quad$ Employment & 1829 & 14.69 & 6 & 0.012 \\
$\quad$ Paddler skill level & 1847 & 8.689 & 2 & 0.013 \\
Issuing paddling licenses & & & & \\
$\quad$ Equipment used to paddle & 1837 & 15.323 & 4 & 0.004 \\
No funding & & 17.330 & 1 & 0.000 \\
$\quad$ Gender & 1827 & 11.488 & 5 & 0.044 \\
$\quad$ Employment & 1829 & 6.618 & 2 & 0.037 \\
$\quad$ Paddler skill level & 1847 & 9.972 & 4 & 0.041 \\
$\quad$ Equipment used to paddle & 1837 & & & \\
\hline
\end{tabular}

issuing paddling licenses (11.0\%). Respondents were able to indicate their support for each funding scheme in dichotomous fashion (support/do not support).

\section{User fees}

Women, $\chi^{2}(1, N=1827)=4.676, p=0.027$, were more likely to support user fees compared with men, and participants with income between $\$ 100,000$ and $\$ 149,000, \chi^{2}$ (6, $N=1763)=14.67, p=0.023$, were also more likely to support user fees as a means of funding paddle trail access (Table 3 ).

\section{Equipment tax}

Paddlers who worked in the private sector, $\chi^{2}(5, N=1829)=13.31, p=0.021$, were less likely than the other employment categories to support equipment tax, while non-profit and public sector employees were more likely to support it.

\section{Craft registration}

Participants with a household income between $\$ 100,000$ and $\$ 149,000, \chi^{2}(6, N=1763)=$ $12.65, p=0.049$, were more likely to support canoe/kayak registration fees, while those making between $\$ 25,000$ and $\$ 49,000$ were less likely to compared with the other income categories. Participants employed in the private sector, $\chi^{2}(5, N=1829)=14.69, p=$ 0.012 , were less likely to support canoe/kayak registration fees as a means of funding paddle access, whereas public sector employees and students were more likely to support boat registration fees. Recreational paddlers, $\chi^{2}(2, N=1847)=8.689, p=0.013$, were more likely to support canoe/kayak registration fees; avid paddlers were less likely to.

\section{Paddling license}

The use of license fees had the least support among respondents. Paddlers who owned canoes, $\chi^{2}(4, N=1837)=15.323, p=0.004$, were less likely to support the use 
of license fees, while paddlers who rented a kayak were more likely to support license fees. Furthermore, kayak renters were more supportive of funding mechanisms than canoe renters; far fewer kayak renters indicated "No funding source" than expected.

\section{No support for the funding mechanisms listed}

Roughly $35 \%$ of the respondents indicated that they did not support any of the funding mechanisms for improved and increased paddle access. Interestingly, the most likely nonsupporters of user funding mechanisms for paddle trail development are those who use the paddle trails the most. Avid paddlers, $\chi^{2}(2, N=1847)=6.618, p=0.037$, and respondents who own canoes or kayaks, $\chi^{2}(4, N=1837)=9.972, p=0.041$, were more likely to not support funding mechanisms. Other groups more likely to not support a funding mechanism were males, $\chi^{2}(1, N=1827)=16.908, p=0.000$, as well as private sector employees, $\chi^{2}(5, N=1829)=11.488$. Despite some of the respondents' lack of support for a user funding mechanism, the need for a sustainable funding mechanism for paddle trails remains (Braswell \& Byrd, 2006; Fix \& Vaske, 2007).

\section{Funding support and perception of paddling as an economic development tool}

The final analysis assessed how paddlers' perceptions toward paddle trail development as a form of economic development affected their propensity to support funding mechanisms. Knowing this would help resource managers and policymakers apply funding strategies to stakeholder groups. When the two response variables were crossed, in each case, those who felt paddling was an economic development tool were more likely to support the particular funding technique in question: user fees, equipment tax, craft registration or paddling license. Those who did not perceive paddling as an economic development tool were more likely to not support any type of funding scheme (Table 4).

The data indicated that all five funding propositions (categories) were significant with the economic development variable. Because of this, a three-way cross-tabulation was conducted to determine which of the mediating responses of economic development (yes/no) was influencing the funding categories. While controlling for participants who indicated that paddling was an economic development tool (yes), four variables - gender, average household income, paddler type and equipment ownership - were significant with at least one of the five different funding categories (Table 5). Age and employment sector were not significant.

\section{Gender}

Results show a significant difference between gender and equipment tax, $\chi^{2}(1, N=$ $1807)=5.288, p=0.021$. A cross-tabulation between the two variables indicated that

Table 4. Chi-square analysis of economic development variable by funding source variables.

\begin{tabular}{lcccc}
\hline Variable & $N$ & $\chi^{2}$ value & df & $p$ \\
\hline Paddling as an economic development tool & & & & \\
$\quad$ User fee & 1826 & 32.476 & 1 & 0.000 \\
Equipment tax & 1826 & 19.113 & 1 & 0.000 \\
Craft registration & 1826 & 43.829 & 1 & 0.000 \\
Paddling license & 1826 & 32.435 & 1 & 0.000 \\
None (support none of the above) & 1826 & 75.183 & 1 & 0.000 \\
\hline
\end{tabular}


Table 5. Three-way chi-square analyses controlling for participants who viewed paddle trails as an economic development tool, and other independent variables by funding source variables.

\begin{tabular}{lcccc}
\hline Variable & $N$ & $\chi^{2}$ value & df & $p$ \\
\hline $\begin{array}{l}\text { Gender } \\
\quad \text { Equipment tax }\end{array}$ & 1807 & 5.288 & 1 & 0.021 \\
$\quad \begin{array}{l}\text { None (support none of the above) } \\
\text { Average income }\end{array}$ & 1807 & 4.995 & 1 & 0.025 \\
$\quad$ User fee & 1746 & 15.759 & 5 & 0.008 \\
$\begin{array}{l}\text { Paddler type } \\
\quad \text { Craft registration }\end{array}$ & 1822 & 9.396 & 2 & 0.009 \\
$\quad$ None (support none of the above) & 1822 & 8.008 & 2 & 0.018 \\
$\begin{array}{l}\text { Equipment used to paddle } \\
\quad \text { Craft registration }\end{array}$ & 1693 & 4.521 & 1 & 0.033 \\
$\quad$ Paddling license & 1693 & 8.207 & 1 & 0.006 \\
$\quad$ None (support none of the above) & 1693 & 4.870 & 1 & 0.027 \\
\hline
\end{tabular}

more males than expected who believed paddling was an economic development tool more likely supported an equipment tax. In addition, more males than expected did not support any type of funding mechanism, $\chi^{2}(1, N=1807)=4.995, p=0.025$.

\section{Household income}

In addition, income levels were also significant for user fee support, $\chi^{2}(5, N=1746)=$ $15.759, p=0.008$. Paddlers with an income level higher than $\$ 100,000$, compared with respondents with lower household incomes, were more likely to support user fees as a means of funding paddle trail access.

\section{Paddler types}

There was also a significant difference between paddler types (avid, recreational and novice) and those who supported canoe/kayak registration fees, $\chi^{2}(2, N=1822)=9.396, p=$ 0.009 . More recreational paddlers than expected supported implementing registrations fees. More avid paddlers than expected did not support any type of funding mechanisms, $\chi^{2}(2$, $N=1822)=8.008, p=0.018$.

\section{Equipment ownership}

The last variable that was significant while controlling for participants who indicated paddling was an economic development tool was equipment ownership, which had two dichotomous response options (own and rent). Participants who rented a kayak/canoe were more likely to support registration fees, $\chi^{2}(2, N=1693)=4.521, p=0.033$, a paddling license, $\chi^{2}(2, N=1693)=8.207, p=0.006$, or not support any type of funding mechanism, $\chi^{2}(2, N=1693)=4.870, p=0.027$, compared to those who owned a kayak/canoe.

\section{Discussion}

A general profile of the paddler who supports any of the various funding mechanisms is female, a recreational paddler, and uses kayak rentals (Table 6). The only income category that yielded significant results was the $\$ 100,000-149,000$ category. User fees were supported by women and paddlers with high household income, more than expected. Craft registration 
Table 6. Summary of funding preferences of North Carolina paddlers more likely to support funding mechanisms.

\begin{tabular}{lcccc}
\hline Variable & User fees & Equipment tax & Craft registration & License \\
\hline Women paddlers & $\mathrm{X}$ & & & \\
Public sector employees & & $\mathrm{X}$ & $\mathrm{X}$ & \\
Nonprofit sector employees & & $\mathrm{X}$ & $\mathrm{X}$ & \\
Recreational paddlers & & & $\mathrm{X}$ & $\mathrm{X}$ \\
Paddlers who rent kayak & $\mathrm{X}$ & & & \\
Paddlers with household income of & & & & \\
$\quad \$ 100-149,000$ & & & & \\
\hline
\end{tabular}

was supported by recreational paddlers and those with a high household income, while licenses were preferred by kayak renters.

As shown in Table 7, the profile of the paddler in this sample who does not support any user funding mechanism is male, employed in the private sector, perceives himself as an avid paddler with high skill level and owns a boat. Bowker et al. (1999) found that recreationists from the southern US were less likely to support recreational fees, a fact that may be supported by the number of paddlers who indicated that they did not support any user funding scheme.

The majority (64\%) of the respondents indicated that they supported some user funding system. This supports the finding that users overall are willing to pay and feel that recreational fees are "fair" (Fix \& Vaske, 2007; Siderelis et al., 2001). However, the impact of income on user fee support has not been very clear in previous research, and the results of the current study do not add a great deal of clarity either. Paddlers with a household income of $\$ 100,000-149,000$ were more likely to support user fees and boat registration, which is consistent with Bowker et al.'s (1999) study findings about higher-income respondents. Paddlers in the lowest-income bracket of less than $\$ 25,000$ were less likely to support craft registration, but this did not show significant deviation from expected scores on the other funding mechanisms, including user fees, which is in discord with the findings of Fix and Vaske (2007). Similar to previous studies, age was not found to be significant in regards to support for user funding options.

\section{Views of paddling as an economic development tool}

Paddler views of paddling as an economic development tool formed themes that overlap with the perspectives on funding schemes (Table 8 ). Female paddlers and recreational paddlers more likely viewed paddle trail development as a form of economic development. In addition, paddlers who were 51 years or older more likely perceived it as a form of economic

Table 7. Summary of funding preferences of North Carolina paddlers less likely to support funding mechanisms.

\begin{tabular}{|c|c|c|c|c|c|}
\hline Variable & User fees & $\begin{array}{l}\text { Equipment } \\
\text { tax }\end{array}$ & $\begin{array}{c}\text { Craft } \\
\text { registration }\end{array}$ & License & $\begin{array}{l}\text { Does not support } \\
\text { any mechanism }\end{array}$ \\
\hline Men & & & & & $\mathrm{X}$ \\
\hline Private sector employees & & $\mathrm{X}$ & $\mathrm{X}$ & & $\mathrm{X}$ \\
\hline Avid paddlers & & & $\mathrm{X}$ & & $\mathrm{X}$ \\
\hline Paddlers who own canoe & & & & $\mathrm{X}$ & $\mathrm{X}$ \\
\hline Paddlers who own kayak & & & & & $\mathrm{X}$ \\
\hline
\end{tabular}


Table 8. Summary of views of North Carolina paddlers on paddling as an economic development (ED) tool.

\begin{tabular}{lcc}
\hline Variable & $\begin{array}{c}\text { More likely to view } \\
\text { paddling as an ED tool }\end{array}$ & $\begin{array}{c}\text { Less likely to view } \\
\text { paddling as an ED tool }\end{array}$ \\
\hline Female paddlers & $\mathrm{X}$ & \\
Avid paddlers & $\mathrm{X}$ & \\
Recreational paddlers & $\mathrm{X}$ & $\mathrm{X}$ \\
Novice paddlers & & $\mathrm{X}$ \\
Younger paddlers (age 18-40) & $\mathrm{X}$ & \\
Older paddlers (age 51+) & & \\
\hline
\end{tabular}

development, whereas paddlers aged 18-40 years did not. However, more importantly, paddlers who viewed paddle trail development as a form of economic development more likely supported a user funding scenario.

Among survey participants who viewed paddle trails as an economic development tool, user fees were supported by paddlers with an income higher than $\$ 100,000$. Equipment taxes were supported by men, craft registration was supported by recreational paddlers and those who rent boats when they paddle, and licenses for boats were supported by boat renters (Table 9).

\section{Recommendations and conclusions}

Findings from this research show that individuals who view paddling as an economic development tool are more likely to support funding mechanisms. Thus, the foundation to creating a sustainable funding source - one in which users are willing to pay - includes marketing and framing users to view paddling as an economic development tool. Several segments exist among those who view paddling as an economic development tool. Understanding these will enable resource managers and policymakers to create funding schemes that maximize the chances of collection and minimize users who would substitute other leisure activities or avoid paying fees through deviant tactics. Recommendations and conclusions listed in this section include strategies to increase the number of stakeholders who view paddling as an economic development tool and ways to optimize collections from various user funding schemes.

\section{Increase tolerance of funding mechanisms}

Creating educational material and programmes that describe paddle trail development as economic development for rural areas should be an initial step in increasing support for

Table 9. Summary of funding preferences of North Carolina paddlers who view paddle trails as an economic development tool.

\begin{tabular}{lccccc}
\hline & $\begin{array}{c}\text { User } \\
\text { fees }\end{array}$ & $\begin{array}{c}\text { Equipment } \\
\text { tax }\end{array}$ & $\begin{array}{c}\text { Craft } \\
\text { registration }\end{array}$ & License & $\begin{array}{c}\text { Does not } \\
\text { support any } \\
\text { mechanism }\end{array}$ \\
\hline $\begin{array}{l}\text { Men } \\
\text { HH income higher than } \$ 100,000\end{array}$ & $\mathrm{X}$ & $\mathrm{X}$ & & & $\mathrm{X}$ \\
$\begin{array}{l}\text { Recreational paddlers } \\
\text { Avid paddlers }\end{array}$ & & & $\mathrm{X}$ & & \\
Paddlers who rent kayak/canoe & & & $\mathrm{X}$ & $\mathrm{X}$ & $\mathrm{X}$ \\
\hline
\end{tabular}


funding paddle trails. Educational material should inform paddlers that their dollars are being invested in the livelihood of communities they visit. The focus of the programming should be to educate the paddlers on the need and benefits of developing and maintaining paddle trail access points. Stakeholders, including residents of paddle trail communities, should also be made aware of the consequences that occur from not having enough funding for the proper upkeep and development of paddle trails, how additional funding could improve the paddling experience and how additional use that improves paddling experiences is good for the community's economic development. Information could be shared through websites, handouts to canoe/kayak renters, kiosks, and paddling clubs and conservation groups.

In addition to providing education about the economic impact of paddle trail development, another way to increase the tolerance of funding mechanisms is to increase economic impacts. The longer visitors stay in a community, the more money they are expected to spend, thus increasing economic benefits in the community. If a large portion of paddlers do not travel far from home to paddle, do not stay long in the paddling destination, but own boats as this survey indicates, then destination marketing organizations in paddle trail communities should develop marketing plans that will entice paddlers to increase their length of stay in paddling destinations. It may also be beneficial to partner with other non-profit and environmental organizations to market the economic benefits as well as to discuss the sustainability aspects of preservation through resource management. This partnership could reduce marketing costs and increase buy-in with these stakeholder groups.

\section{Optimize funding collection}

Based on the data collected regarding the perspectives of paddlers on how paddle trails should be funded, the optimal funding strategy could be a combination of boat registration and user fees for those who do not own boats.

As discussed, heavy-use groups such as avid paddlers and those who own boats are more likely to support "no funding mechanism" than to support any particular funding scheme. Therefore, it can be assumed that some paddlers in the heavy-use groups would avoid paying user fees by utilizing unauthorized access to sensitive landscapes or illegally accessed property (Braswell \& Byrd, 2006). Similarly, paddlers wanting to avoid user fees could also enter sounds and rivers from authorized private or public beaches, a scenario prevalent throughout NC. Instead of collecting user fees, funding via boat registration is one preferable alternative. Previous studies have shown that annual fees would have less of a negative impact on future demand than recurring user fees for paddle trail users (Siderelis \& Moore, 2006; Siderelis et al., 2001). In this regard, if both one-time user fees and a less expensive annual pass were incorporated as options for payment, it may capture the more frequent users at a discounted rate as well as those paying for each use.

Another alternative could be provided for boat owners who might not want to register their vessel. Those opposed to registering their boats could have the option to join a "friends of" group responsible for preservation of the waterways. Being part of a group designed to protect paddle trails would provide those who are more invested in the paddle trails (i.e. boat owners and avid paddlers) with a greater sense of ownership, which could lead to increased stewardship.

Kayak renters and recreational paddlers seem more amenable to user funding schemes. Thus, the "recreational" and "novice" paddler could be targeted first by implementing a small "pay to play" fee on rentals. Natural resource managers in defined and controlled areas, such as parks, might implement a pilot user fee program at various sites, while assessing 
paddler reactions. When purchasing a rental package that includes guided instruction, meals and other amenities, a small flat fee may not be noticed nor met with market resistance.

Private sector employees who might possibly be more fiscally conservative and/or generally oppose "taxation" might respond more positively to a "pay to play" license as this would be in line with a market mentality. Similar consumptive activities such as fishing and hunting are also sometimes regulated with licenses; therefore, the familiarity with this system might seem more favorable than an equipment "tax". Understanding which funding mechanism is most supported is an important aspect to any sustainable resource management.

\section{Limitations and future research}

This sample consisted of NC residents only and is a convenience sample. Therefore, the results are not generalizable to other locations or recreational activities. Notably, caution must be taken in interpreting the results of the chi-square test for independence in that it tests the hypothesis that variables are related only by chance. If a significant relationship is found, such as in the case of this study, this is not equivalent to a causal relationship. Furthermore, the power of a chi-square test to reject the null hypothesis is low. Therefore, a chi-square test indicating a nonsignificant relationship, as is the case in this study with variables of age and activity level, may lead researchers to believe data in the sample occurred by chance. However, care should be taken not to assume that lack of contradictory evidence differs from data supporting the hypothesis. The sample in the current study was large, which strengthens the results of the chi-square test. The chi-square test was appropriate for the question format, which was dictated by the authority sponsoring the research.

Future studies should look at the significant variables to predict which funding sources they would support or not support. Additionally, studies should consider the economic impact of each type of paddler, and the economic impact of paddle trails within the context of community development. Future research in this area may also consider regression analysis or structural equation modeling as a more sophisticated means for handling the complexity of data involved in paddle trail development. Other factors examined should include previous experience with paddling, paddler companions/party, motivations for paddling and paddler commitment as related to support for user funding schemes. And certainly, the interplay between the input variables (such as skill level, boat ownership and annual number of trips) must be considered to more accurately target paddler submarkets.

Based on the data, the most avid paddlers are the least likely to approve of user funding schemes. This particular group of paddlers seems to have the greatest investment in paddling because they spend the most time and resources on the activity. Thus, it appears to be contradictory to what would be expected since they would be the ones benefiting the most from the funding. Additional research should be conducted to learn more about their attitudes toward the need for paddle trail expansion and enhancement, other users of paddle trails, funding methods and intermediary agencies that collect and handle funds.

Government funding earmarked to expand and maintain natural resources and its related access and infrastructure remains flat or in decline. Often, a "pay to play" funding mechanism is employed by park mangers at a local level to aid in economic sustainability of a resource. Paddlers, and recreationists overall, are not all alike, however, and resistance from them regarding funding schemes can be met with a greater understanding of market segments, defined by socio-demographics, trip behavior, and/or motivations and attitudes. This study used socio-demographic and trip behavior paddler segments to explore the support for various user funding options from paddlers in NC. If managers and planners have a 
greater understanding of paddler segments and their support for different funding options,

implementation of sustainable funding streams might be more successful.

\section{Acknowledgments}

The authors would like to thank Marlise Moody from the North Carolina Division of Tourism, Film and Sports Development, Raleigh, North Carolina, for visitation statistics on North Carolina visitation, and Ken Cordell of the Southern Research Station, USDA Forest Service, Athens, Georgia, for access to NSRE fee data. Additionally, Darrell McBane and Bayard Alcorn from the North Carolina Department of Environment and Natural Resources provided the data from the 2008 Paddling Tourism Study as well as fee information from North Carolina State Parks. Thank you to Brian Bulla for developing the map of $\mathrm{NC}$ paddle trails.

\section{Notes on contributors}

Carol Kline is Assistant Professor at the Center for Sustainable Tourism/Recreation and Leisure Studies at East Carolina University and has worked in the area of rural tourism planning, development and marketing for nearly 20 years. Her work focuses on how entrepreneurial climate and community capitals influence rural tourism development, the intersection of the sustainable food system and tourism, and niche forms of tourism in burgeoning destinations, such as the scientific or research tourism market. She has worked in many U.S. regions, as well as in Ghana, Peru, Grenada and Cuba.

David A. Cardenas is Assistant Professor at the University of South Carolina and Research Fellow at the Center of Economic Excellence in Tourism and Economic Development. He is currently conducting research on stakeholders understanding and involvement in the sustainable tourism development process. His research interests include sustainable tourism development, community development, study abroad and international tourism education.

Lauren Duffy is a PhD student in Leisure Behavior at Indiana University, with a research focus on gender and tourism, sustainable tourism planning and international education. She has been involved with tourism projects in Ecuador, El Salvador and the Dominican Republic and is currently working on her dissertation research that looks at tourism planning from a gender and development framework in Latin America.

Jason R. Swanson is Assistant Professor in the Hospitality Management and Tourism program at the University of Kentucky and is an adjunct graduate faculty member at Assumption University in Bangkok, Thailand. His research interests include destination strategic planning, communitybased tourism development, tourism trade association management, public policy development and advocacy, and qualitative methods. He also co-authored a textbook titled Tourism Policy and Planning: Yesterday, Today, and Tomorrow in 2008. Jason's industry experience includes hotel operations, market/feasibility analysis and tourism development. He has worked for consulting clients in over 50 markets throughout the United States, the Caribbean and Asia.

\section{References}

American Canoe Association (ACA). (n.d.). Water trails database. Retrieved June 16, 2010, from $\mathrm{http}: / /$ www.americancanoe.org/members/group_select.asp?type $=7731$

Argow, K.A., \& Fedkiw, J. (1963). Recreation user fee income: How far does it go towards meeting costs? Journal of Forestry, 61(10), 751-753.

Binkley, C.S., \& Mendelsohn, R.O. (1987). Recreation user fees: An economic analysis. Journal of Forestry, 85(5), 31-35.

Bixler, R., \& Morris, B. (2000). Factors differentiating water-based wildland recreationists from nonparticipants: Implications for recreation activity instruction. Journal of Park and Recreation Administration, 18(2), 54-72.

Bowker, J.M., Cordell, H.K., \& Johnson, C.Y. (1999). User fees for recreational services on public lands: A national assessment. Journal of Park and Recreation Administration, 17(3), 1-14.

Bowker, J.M., \& Leeworthy, V.R. (1998). Accounting for ethnicity in recreation demand: A flexible count data approach. Journal of Leisure Research, 30(1), 64-78.

Braswell, J.D., \& Byrd, E.T. (2006). Visitor access to non-motorized boating areas. E-Review of Tourism Research, 4(4). Retrieved November 20, 2009, from http://ertr.tamu.edu/pdfs/a-110.pdf. 
Briedenhann, J., \& Wickens, E. (2004). Tourism routes as a tool for the economic development of rural areas - Vibrant hope or impossible dream? Tourism Management, 25, 71-79.

Bryan, H. (1977). Leisure value systems and recreation specialization: The case of trout fishermen. Journal of Leisure Research, 9, 174-187.

Cordell, K. (2008). The latest on trends in outdoor recreation. Forest History Today, Spring, 4-10.

Cordell, K., \& Betz, C. (2000). Trends in outdoor recreation supply on public and private lands in the U.S. In W.C. Gartner \& D.W. Lime (Eds.), Trends in outdoor recreation, leisure and tourism (pp. 75-90). Wallingford: CABI Publishing.

Dickinson, J.E., Lumsdon, L.M., \& Robbins, D. (2011). Slow tourism: Issues for tourism and climate change. Journal of Sustainable Tourism, 19(3), 281-300.

Dillman, D. (2000). Mail and internet surveys: The tailored design method. New York, NY: Wiley.

Fix, P.J., \& Vaske, J.J. (2007). Visitor evaluations for recreation user fees at Flaming Gorge national recreation area. Journal of Leisure Research, 39(4), 611-622.

Gallardo, J.H., \& Stein, T.V. (2007). Participation, power, and racial representation: Negotiating nature-based and heritage tourism development in the rural south. Society and Natural Resources, 20,597-611.

Glaser, M.A., \& Hildreth, W.B. (1996). A profile of discontinuity between citizen demand and willingness to pay taxes: Comprehensive planning for park and recreation investment. Public Budgeting and Finance, 16(4), 96-113.

Grossmann, M., Klaphake, A., \& Meyerhoff, J. (2004). Canoes versus birds or canoeists versus canoeists? Combining interview survey and visitor monitoring to inform visitor management in the Mueritz National Park. Papers of the Finnish Forest Institute, 2, 277-284.

Harris, C.C., \& Driver, B.L. (1987). Recreation user fees: Pros and cons. Journal of Forestry, 85(1), $25-29$.

Hynes, S., \& Hanley, N. (2006). Preservation versus development on Irish rivers: Whitewater kayaking and hydro-power in Ireland. Land Use Policy, 23, 170-180.

Hynes, S., Hanley, N., \& Garvey, E. (2007). Up the proverbial creak without a paddle: Accounting for variable participant skills levels in recreational demand modelling. Environmental \& Resource Economics, 36, 413-426.

Jennings, T. (2010). A river runs through it: Assessing the attitudes of landowners along the luling paddle trail (Master's thesis). Department of Political Science, Texas State University-San Marcos). Retrieved January 3, 2011, from http://ecommons.txstate.edu/arp/327

Kim, S., Scott, D., \& Crompton, J. (1997). An exploration of the relationships among social psychological involvement, behavioral involvement, and future intentions in the context of birdwatching. Journal of Leisure Research, 29(3), 320-341.

Krizek, K. (2007). Estimating the economic benefits of bicycling and bicycle facilities: An interpretive review and proposed methods. In P. Coto Milan \& V. Inglada (Eds.), Essays on transporteconomics (pp. 219-248). Heidelbesrg, NY: Springer.

Kuentzel, W.F., \& Heberlein, T.A. (2006). From novice to expert? A panel study of specialization progress and change. Journal of Leisure Research, 38(4), 496-512.

Kyle, G.T., Graefe, A.R., \& Absher, J.D. (2002). Determining appropriate prices for recreation on public lands. Journal of Park and Recreation Administration, 20(2), 69-89.

Lane, B. (1994). Sustainable rural tourism strategies: A tool for development and conservation. Journal of Sustainable Tourism, 2(1-2), 102-111.

Lane, B. (2009). Rural tourism: An overview. In T. Jamal \& M. Robinson (Eds.), The Sage handbook of tourism studies (pp. 354-370). London: Sage.

Lee, S.-H., Graefe, A.R., \& Li, C.-L. (2007). The effects of specialization and gender motivations and preferences for site attributes in paddling. Leisure Sciences, 29, 355-373.

Lee, C., Lee, J., Kim, T., \& Mjelde, J.W. (2010). Preferences and willingness to pay for bird-watching tour and interpretive services using a choice experiment. Journal of Sustainable Tourism, 18(5), 695-708.

Lindsey, G., Man, J., Payton, S., \& Dickson, K. (2004). Property values, recreation values, and urban greenways. Journal of Park and Recreation Administration, 22(3), 69-90.

Lumsdon, L.M., \& McGrath, P. (2011). Developing a conceptual framework for slow travel: A grounded theory approach. Journal of Sustainable Tourism, 19(3), 265-280.

Marsinko, A., Dwyer, J., \& Schroeder, H. (2003). Attitudes towards fees and perceptions of costs of participating in day-use outdoor recreation. In Proceedings of the 2003 Northeastern Recreation 
Research Symposium (General Technical Report No. GTR-NE-317) (pp. 278-284). Newtown Square, PA: US Department of Agriculture, Forest Service, Northeastern Research Station.

Meyer, R. (1999). Activity involvement, equipment, and geographic connection to recreation area: The case of boaters in southeastern Norway. Norwegian Journal of Geography, 53(1), $17-27$.

Moore, R.L., Scott, D., \& Moore, A. (2008). Gender-based differences in birdwatchers' participation and commitment. Human Dimensions of Wildlife, 13(2), 89-101.

Moore, S.A., \& Rodger, K. (2010). Wildlife tourism as a common pool resource issue: Enabling conditions for sustainability governance. Journal of Sustainable Tourism, 18(7), 831-844.

Moore, R.L., \& Shafer, C.S. (2001). Introduction to special issue trails and greenways: Opportunities for planners, managers, and scholars. Journal of Park and Recreation Administration, 19(3), $1-16$.

Mowen, A.J., Graefe, A.R., \& Williams, D.R. (1998). An assessment of activity and trail type as indicators of trail user diversity. Journal of Park and Recreation Administration, 16(1), 80-96.

Mowen, A.J., Kyle, G.T., Borrie, W.T., \& Graefe, A.R. (2006). Public response to park and recreation funding and cost-saving strategies: The role of organizational trust and commitment. Journal of Park and Recreation Administration, 24(3), 72-95.

Nadel, R.E. (2005). Economic impact of parks, rivers, trails and greenways (Unpublished master's thesis). University of Michigan, Ann Arbor, MI.

Nicholls, S., \& Crompton, J.L. (2005). The impact of greenways on property values: Evidence from Austin, Texas. Journal of Leisure Research, 37(3), 321-341.

North Carolina General Assembly, North Carolina Administrative Code. 15A NCAC 12B.1206: Fees and charges (Amended 2004). Raleigh, NC: Office of Administrative Hearings.

North Carolina Division of Parks and Recreation (NCDPR). (2008, December). North Carolina outdoor recreation plan 2009-2013 (NC Department of Environment and Natural Resources). Retrieved June 23, 2010, from http://www.ncparks.gov/About/plans/scorp/main.php

North Carolina Division of Tourism, Film and Sports Development. (2009). Tourism research. Retrieved June 26, 2010, from http://www.nccommerce.com/tourism/research

Nyaupane, G.P., Graefe, A.R., \& Burns, R.C. (2009). The role of equity, trust and information on user fee acceptance in protected areas and other public lands: A structural model. Journal of Sustainable Tourism, 17(4), 501-517.

Oh, C., \& Hammitt, W.E. (2010). Determining economic benefits of park trails: Management implications. Journal of Park and Recreation Administration, 28(2), 94-107.

Ostergren, D., Solop, F.I., \& Hagen, K.K. (2005). National park service fees: Value for the money or a barrier to visitation? Journal of Park and Recreation Administration, 23(1), 18-36.

Pollock, N. (2007). The northern forest canoe trail: Economic impacts and implications for sustainable community development (Unpublished master's thesis). University of Vermont, Burlington, VT.

Portland Parks \& Recreation. (2006). Recreational trail strategy: A 20-year vision for Portland's regional trail system. Retrieved August 3, 2010, from http://www.portlandonline.com/parks/ index.cfm? $=42627$

Pouta, E., Neuvonen, M., \& Sievanen, T. (2006). Determinants of nature trip expenditures in southern Finland: Implications for nature tourism development. Scandinavian Journal of Hospitality and Tourism, 6(2), 118-135.

Reiling, S.D., Cheng, H.-T., Robinson, C., McCarville, R.E., \& White, C. (1995, April 6-7). Potential equity effects of a new day-use fee. Paper presented at the Northeastern Recreation Research Symposium, Saratoga Springs, NY.

River Federation. (January, 1997). Funding river conservation in the states: Diverse sources, promising trends (A report prepared in cooperation with the National Park Service, Rivers, Trails and Conservation Assistance Program). Springfield, MD: River Federation.

Schuett, M.A. (1995). Predictors of social group participation in whitewater kayaking. Journal of Park and Recreation Administration, 13(2), 42-54.

Schutt, A.M. (1998). Trails for economic development: A case study. Journal of Applied Recreation Research, 23(2), 127-145.

Settina, N., \& Kauffman, R. (2001, September). Water trails. Parks and Recreation Magazine, pp. 94-102.

Shafer, E., \& Choi, Y. (2006). Forging nature-based tourism policy issues: A case study in Pennsylvania. Tourism Management, 27, 615-628. 
Shafer, C.S., Lee, B.K., \& Turner, S. (2000). A tale of three greenways trails: User perceptions related to quality of life. Landscape and Urban Planning, 49, 163-178.

Siderelis, C., \& Moore, R. (2006). Examining the effects of hypothetical modifications in permitting procedures and river conditions on whitewater boating behavior. Journal of Leisure Research, $38(4), 558-574$.

Siderelis, C., Whitehead, J., \& Thigpen, J. (2001). Paddle trails and contingent fee data. North Carolina coastal plains paddle trails initiative: 2001. In Coastal Plains Paddle Trails Research Proceedings (pp. 66-79). Raleigh, NC: North Carolina Sea Grant, NC State University.

Snyder, S.A., \& Smail, R.A. (2009). Are all-terrain vehicle riders willing to pay trail user fees to ride on public lands in the USA? Tourism Economics, 15(2), 437-451.

Southwick, R., Bergstrom, J., \& Wall, C. (2009). The economic contributions of human-powered outdoor recreation to the US economy. Tourism Economics, 15(4), 709-733.

Thigpen, J., Avant, B., \& Siderelis, C. (2001). The state of North Carolina coastal paddling 2001. In North Carolina Coastal Plains Paddle Trails Initiative: 2001 Coastal Plains Paddle Trails Research Proceedings (pp. 14-28). Raleigh, NC: North Carolina Sea Grant, NC State University.

Trask, J.E. (2006). How to build a paddle trail in your community: The development of a statewide paddle trail model for North Carolina (Unpublished master's thesis). North Carolina State University, Raleigh, NC.

Turner, S. (2001). Tourism, the environment and rural development. In J.K. Coetzee, J. Graaf, F. Hendricks, \& G. Wood (Eds.), Development: Theory, policy and practice (pp. 361-375). Cape Town: Oxford University Press.

US Environmental Protection Agency. (2003, September). Building capacity for nonpoint source management: Case studies report. Washington, DC: US Environmental Protection Agency.

Watson, A.E., \& Herath, G. (1999). Research implications of the theme issues "Recreation fees and pricing issues in the public sector" (Journal of Park and Recreation Administration) and "Societal response to recreation fees on public lands" (Journal of Leisure Research). Journal of Leisure Research, 31(3), 325-334.

Winter, P.L., Palucki, L.J., \& Burkhardt, R.L. (1999). Anticipated responses to a fee program: The key is trust. Journal of Leisure Research, 31(3), 207-226. 